\title{
チタン合金とニッケル合金の高速研削のための 新しいダイヤモンド電着工具と炎の強制冷却システムの開発*
}

\author{
田 辺 郁 男*1, HOANG Thang Binh*1 \\ 井山徹 郎*1, Eike KRATZ*2
}

\section{Development of New Electro Deposited Diamond Tool and Its Compulsory Cooling System for High Speed Grinding of Titanium and Nickel Alloys}

Ikuo TANABE*3, HOANG Thang Binh, Tetsuro IYAMA and Eike KRATZ

\footnotetext{
${ }^{* 3}$ Central Machine Shop, Nagaoka University of Technology,

1603-1 Kamitomioka-machi, Nagaoka-shi, Niigata, 940-2188 Japan
}

\begin{abstract}
Recently titanium alloys and nickel alloys have become eminent for making aeronautic and astronautic parts. Since both nickel alloys and titanium alloys have a very small thermal conductivity, the being used tool will suffer from a huge damage by heat generated during grinding process. Therefore, there is a requirement for a durable tool with excellent cooling capacity. In this research, a new electro-deposited diamond tool for high speed grinding of nickel alloys and titanium alloys was developed and evaluated. The new tool is a cup shaped end mill, its body is made from copper (due to its superior heat conduction characteristics) and the platting layer for bonding the diamond grains \#120 is nickel. The cooling system is an advancement of the former used heat pipe. Water is supplied from outside through a thin tube, that is integrated in the tool body. Thereby the effect of water evaporation, featuring a very large cooling capacity, could be applied. The assayed materials were Ti 6 A $14 \mathrm{~V}$ and Inconel 718. The grinding conditions were investigated by some preexperiments. It is concluded from the results that; (1) The cooling capacity of the new tool using water evaporation is very effective to maintain the grinding potential of electro-deposited diamond tools, (2) The new tool is effective for high speed grinding of nickel alloys and titanium alloys, ( 3 ) The new tool and compulsory cooling system are economical and eco-friendly.
\end{abstract}

Key Words: High Speed Grinding, Titanium Alloy, Nickel Alloy, Compulsory Cooling, Tool Life

\section{1. 粕 言}

最近，チタン合金やニッケル合金は航空機材料とし て多用されており，容易かつ高精度にそれらを加工す る方法が検討されている(1),(2),(3). しかし，この二材 料はいずれも熱伝導率が低く，加工の際に発生した熱 の多くが工具に集中的に熱伝導されるため, 工具が高 温になり，自身の硬さや機械的強度が著しく低下した 状態で加工することになる．また，工具材料としてダ イヤモンドを考えると， $300^{\circ} \mathrm{C}$ ま゙は硬度や機械的強 度が温度上昇に依存しない材料であり，工具先端温度 $300^{\circ} \mathrm{C}$ を限度としてチタン合金やニッケル合金の加工 に有効利用できると考えられる。

一方, 著者らはボールエンドミル形状のダイヤモン ド電着工具の内部にヒートパイプを構成し，工具の内 部から連続的に強制冷却することによって, 超硬を乾

\footnotetext{
* 原稿受付 2008 年 5 月 26 日.

*1 正員, 長岡技術科学大学機械系(焉940-2188 長岡市上富岡 町 1603-1).

*2 長岡技術科学大学工学部.

E-mail : tanabe@mech.nagaokaut.ac.jp
}

式研削した場合の四倍の工具寿命で加工できることを 明らかにした ${ }^{(4)}$.

本研究では，チタン合金やニッケル合金などの難削 材を効率よく研削するために，冷却効率のよいダイヤ モンド電着工具を開発し, さらに, 先のヒートパイプ 型工具よりも効率よく強制冷却するための冷却システ ムを開発する. 最後に, 開発した工具と強制冷却シス テムを用いて, 研削加工時の工具温度測定と工具寿命 測定を行って，工業的な有效性を評価する.

\section{2. 新しいダイヤモンド電着エ具と その強制冷却システムの開発}

\section{1 従来のヒートパイプ内䑏ダイヤモンド要着} 工具の問題点 図 1 に著者らが先の研究 (1)で開発し たヒートパイプ内藏のダイヤモンド電着工具の概略 図を示す。これは，従来のダイヤモンド電着工具の内 部に穴を開け，水とエタノールの混合物を椧却媒体 として封入したものである。また，このヒートパイプ 型ダイヤモンド電着工具はコレートチャックで保持さ れた後，その上部には水冷層が設けられ，そこで気化 熱(5)、(6)、(汭による水冷が行われる。これにより，超硬を 
乾式研削した場合の四倍の工具寿命で加工できた.

外部からの研削油剤をかけることによる強制冷却で は，工具の高速回転から生じる遠心力や空気の連れ回 り層があることによって，供給した研削油剤が刃先先 端に十分にかからなかったり，エアーカット時のみし か研削油剤が刃先先端にかからなかった。これに対し て, この工具内部にヒートパイプ機能を内蔵させて強 制冷却するシステムは, 連続的に強制冷却でき, 電気 エネルギーを使用せず，水の気化熱のみを使用してい るため, 作業者の健康と地球環境の保全にも貢献して いた.

しかし, ダイヤモンドは熱伝導率が大きく, ヒート シンクも大きいものの, このダイヤモンドとヒートパ イプ機構の間には, 熱伝導率が小さい工具本体のステ ンレス鋼 SUS304 と電着用の鍍金材料のニッケルが存 在し，あたかも断熱材の役目をして，強制冷却を阻害 する大きな要因であった。 また，ヒートパイプ機能を 通して間接的に気化熱冷却しているために，全体の冷 却効率が低下せざるを得なかった。

\section{2 冷却効事を考虑したダイヤモンド而着工具}

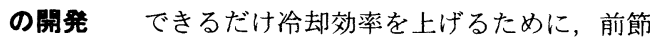
のダイヤモンド電着工具の本体および電着用の鍍金の 材料を考察する. 表 1 に選択対象として考えられる材 料の熱伝導率を示す. 図 2 には工具本体と電着用の鍍 金にいろいろな材料を使用したときの見かけ上の熱伝 導率を計算するための熱解析用 FEM モデルを示す. ダ イヤモンド電着工具の集中度から計算した砥粒 1 つぶ 当たりの工具半径方向のモデルである．4つの側面は すべて断熱として, ダイヤモンドに熱流束を与え, 工

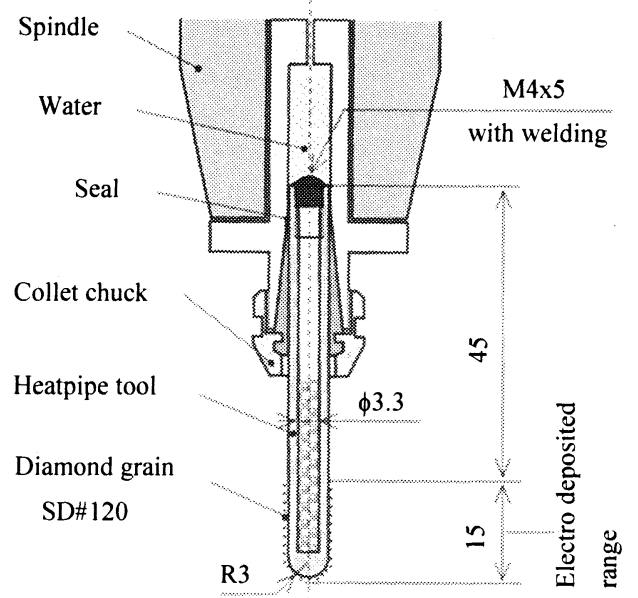

Fig. 1 The cooling system using the electro-deposited diamond tool with heat pipe function inside
具内壁は $0^{\circ} \mathrm{C}$ と $10 \mathrm{~W} / \mathrm{m}^{2} \cdot \mathrm{K}$ で熱伝達したときの定常熱伝 導計算をする. この FEM モデルで, 工具本体と電着用 の鍍金をいろいろな材料の組合せにしたときのダイヤ モンド表面温度と工具内壁温度の温度差に対して，モ デル材質が同一と仮定して計算した温度差が同じにな ったとき，その均一と仮定したモデル材質の熱伝導率 を見かけ上の熱伝導率とした。

図 3 に工具本体と電着用の鍍金にいろいろな材料を 使用したときの見かけ上の熱伝導率の計算結果を示す. 工具本体をステンレス鋼SUS304 から銅にすることによ って, ニッケル鍍金の場合は 12 倍程度, 銅鍍金の場合 は20 倍程度見かけ上の熱伝導率が大きくなった。この 計算で使用した工具本体と電着用の鍍金の材質の組合 せの中で，工具本体と電着用の鍍金ともに銅にした場 合が最も見かけ上の熱伝導率が大きくでき，つぎに大 きいのは，工具本体が銅で電着用の鍍金をニッケルに した場合であった。

つぎに, 工具本体に銅，電着用鍍金に銅もしくはニ ッケルを使用した場合の機械的強度を FEM によって考 察した．図 4 に鍍金層の強度を考察するための解析用

Table 1 Thermal conductivity of each material for new electro-deposited diamond tool

\begin{tabular}{|l|c|}
\hline \multicolumn{1}{|c|}{ Material } & Thermal conductivity W/mK \\
\hline Diamond (PCD) & 2000 \\
\hline Copper & 390 \\
\hline Aluminum & 210 \\
\hline Nickel & 43 \\
\hline S45C & 50 \\
\hline SUS304 & 16 \\
\hline
\end{tabular}

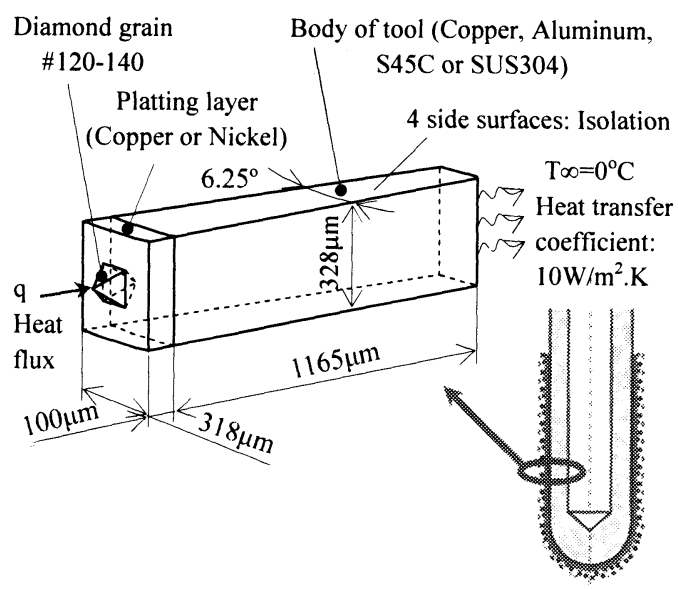

Fig.2 FEM model for calculation of apparent thermal conductivity regarding electro-deposited diamond tool 
FEM モデルを示す. 図 2 と同様の形状のモデルであり， モデルの 4 つの側面は隣接する部分とのひずみの対象

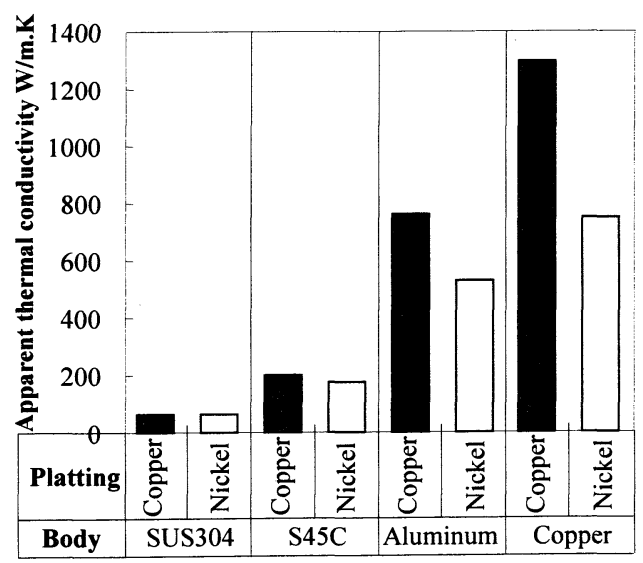

Fig.3 Relationship between apparent thermal conductivity and combination of tool materials

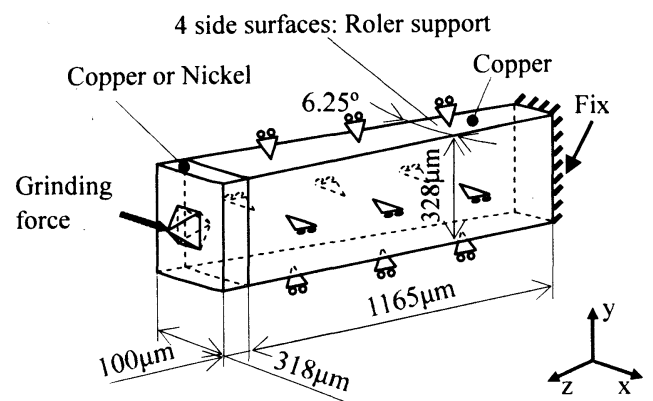

Fig. 4 FEM model for calculation of mechanical strength regarding new electro-deposited diamond tool

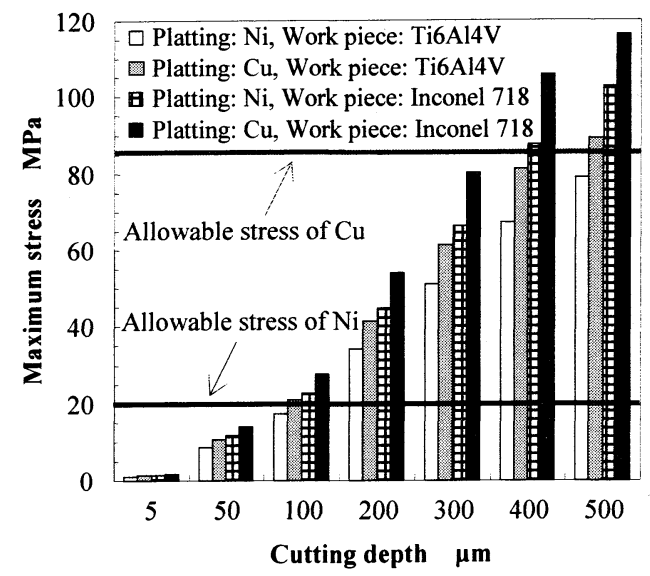

Fig. 5 Calculation results of mechanical strength regarding new electro-deposited diamond tool
面と考え，面直角方向にローラ支持とし，工具の内壁 は固定とした。ダイヤモンド砥粒には切込み量と工作 物の比研削抵抗に応じて研削方向 (X方向) に面圧をか けた. 図 5 に切込み量と鍍金層の最大応力（VonMises） の関係を示す. 前の研究 ${ }^{(4)}$ で推奨される加工条件は, 工作物が超硬 V10 では，切込み量が $5 \mu \mathrm{m}$ であったが, それに比べて工具本体に銅，電着用鍍金に銅もしくは ニッケルを使用した場合で, $50 \mu \mathrm{m}$ 程度の梁い切込みに しても，使用している銅やニッケルの許容応力に至る ことはなく, 従来の一般的な電着工具（工具本体が SUS304 かS45Cで，ダイヤモンドをニッケル鍍金）を， 工具本体に銅，ダイヤモンド電着用鍍金に銅もしくは ニッケルに代えた場合でも，研削には十分な強度を有 していると考えられる.

なお，ダイヤモンドを銅鍍金で電着することが困難 であったため, 本報では工具本体の銅に $0.5 \mu \mathrm{m}$ のニッ ケル鍍金を施した後に，ニッケル鍍金でダイヤモンド 電着をした。

また，工具全体モデルでは，工作物が Incone1 718 である場合, 切り込み量が $500 \mu \mathrm{m}$ であった時の研削抵 抗力と $50000 \mathrm{~min}^{-1}$ 高回転による遠心力を受けても工具 をコレットチャックに固定する部分の最大応力は 9.9 MPa であり, 銅の許容応力の 8 分の 1 に至ることはなく 銅製工具を使用しても問題ないと考えられる.

2. 3 内部気化熱冷却システムの開発 前節で 開発した新しいダイヤモンド電着工具の内側を効率よ く強制冷却するために，内部気化熱冷却システムを開 発した. 図 6 にそのシステムの説明を示す. 高速スピ ンドルユニットの上面から穴をあけ，そこに外径 2.0

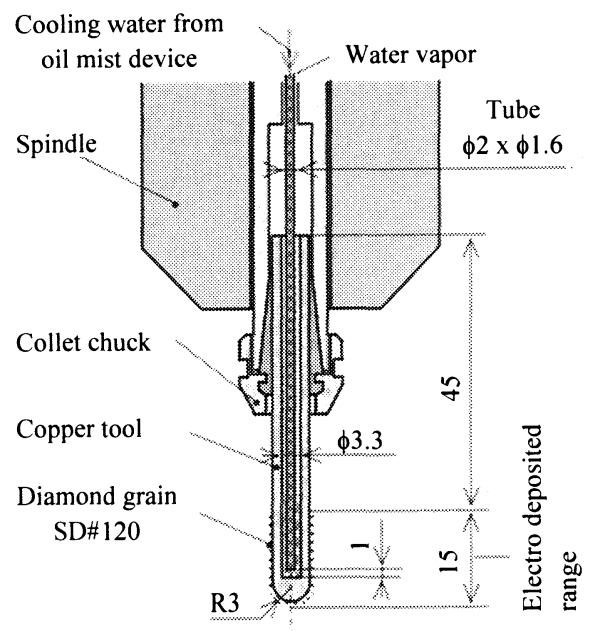

Fig. 6 Schematic view of the compulsory cooling system inside the new electro-deposited diamond tool 
$\mathrm{mm}$ (内径 $1.6 \mathrm{~mm})$ のステンレス製パイプを通し，その パイプ先端がダイヤモンド電着工具の内部の底から $1.0 \mathrm{~mm}$ の位置になるようにセットし, パイプが電着工 具の回転で連れまわられないように, パイプを高速ス ピンドルユニットの筐体に固定する，ステンレス製パ イプのもう一端はオイルミスト装置に連結する。この オイルミスト装置には水のみを供給し, 微量の水を連 続的に供給する装置として使用する.

本開発の内部気化熱泠却工具は, 砥粒であるダイヤ モンドのヒートシンクの良さを最大限に引き出せるよ うに，工具本体を銅として工具内壁までの良好な熱伝 導経路を確保し, さらに, 冷却効率を上げるためにダ イレクトの気化熱冷却ができるような強制冷却システ ムを搭載した。

\section{3. チタン合金とニッケル合金の加エに よる開発システムの評価}

3. 1 評洒方法 前章で開発した新しいダイヤ モンド電着工具とその強制冷却システムで, チタン合 金とニッケル合金の工作物を加工した際の研削特性を 測定し，その有效性を評価する. 表 2 に評価実験のた めの加工条件, 図 7 に加工の様子をそれぞれ示す. 開 発したダイヤモンド電着工具を高速スピンドルユニッ トに装着し, 主軸回転数を $50000 \mathrm{~min}^{-1}$, 工具と工作物 の接触長さ $8 \mathrm{~mm}$ で切込みを $1 \sim 3 \mu \mathrm{m}$ として, 1 パスあ たり $50 \mathrm{~mm}$ の切削を往復で行った. その際の送り速度 は $1250 \mathrm{~mm} / \mathrm{min}$ とした。これは, 切削音, 振動, 工具 の安定性, 生産性の観点から推奨できると判断した加 工条件である. 工作物は Ti6Al4V および Inconel 718 を使用した。

Table 2 Grinding conditions for evaluation

\begin{tabular}{|l|l|}
\hline Tool size & \$6 mm $\times 60 \mathrm{~mm}$ length \\
\hline Work pieces & $\begin{array}{l}\text { Ti6Al4V: Hardness HRC 39, } \\
\text { Specific grinding force 2470 MPa } \\
\text { Inconel 718: Hardness HRC 36, } \\
\text { Specific grinding force 3220 MPa }\end{array}$ \\
\hline Work piece size & $50 \mathrm{~mm} \times 50 \mathrm{~mm} \times 25 \mathrm{~mm}$ \\
\hline Spindle speed & $50000 \mathrm{~min}^{-1}$ \\
\hline Grinding depth & $1,2,3 \mu \mathrm{m}$ \\
\hline Feed speed & $1250 \mathrm{~mm} / \mathrm{min}^{-12}$ \\
\hline $\begin{array}{l}\text { Contact length } \\
\text { between tool and } \\
\text { work piece }\end{array}$ & $8 \mathrm{~mm}$ \\
\hline Cutting distance & $50 \mathrm{~mm} / 1$ pass \\
\hline
\end{tabular}

図 8 に温度測定のセットアップを示す．温度測定に は放射型温度計を使用し，ダイヤモンド電着工具がエ アーカットを始める部分の温度を加工点から $300 \mathrm{~mm}$ 離 れた所で測定した。

図 9 に工具寿命判定方法と加工量測定方法の写真を 示す. 図 9 (a)はマイクロスコープで観察した使用前後 のダイヤモンド砥粒の写真である，砥粒が平均的に右 側の状態になったときを寿命と判定することにした。

これとは別に, $1 \mu \mathrm{m}$ 精度のマイクロメータで工具の直 径の減少量を測定したところ, 摩耗による直径減少量 が $0.085 \mathrm{~mm}$ になった時点で, ダイヤモンド砥粒が平均 的に図 9(a) 右図のようになることが確認されたため, 簡易的な工具寿命判定方法として，工具の加工部上・ 中・下段の各円周部 3 箇所 $\left(120^{\circ} こ ゙ と\right)$ の直径減少量 の平均値が $0.085 \mathrm{~mm}$ になった時点を工具寿命とした。

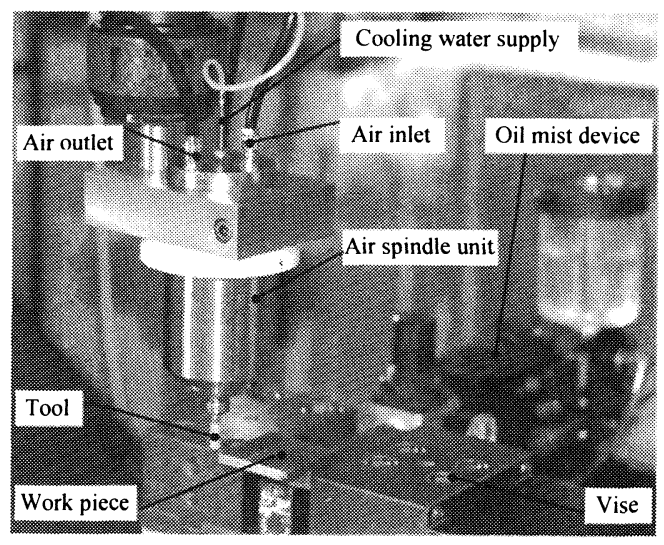

Fig. 7 Photogragh of the grinding system using new electro-deposited diamond tool and its forced cooling system

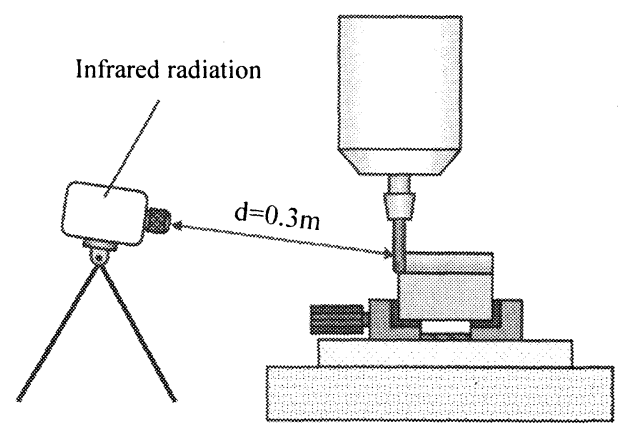

Fig. 8 Schematic view for measuring temperature on the electro-deposited diamond tool 
図 9(b)では, 1 パスごとに電着工具が左方向に $3 \mu \mathrm{m}$

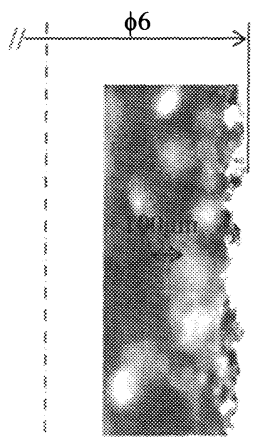

New tool

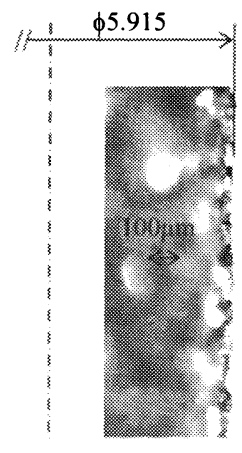

Used tool (a) Wear of a ball end-mill

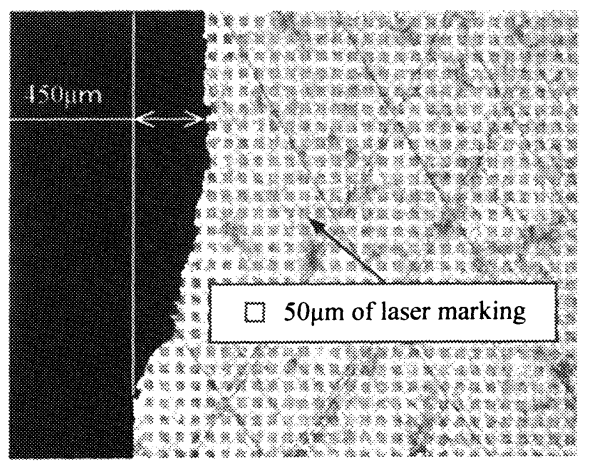

(b) Work piece with laser marking

Fig. 9 Photograph of electro-deposited diamond of both pre-grinding and after grinding and the work piece with laser mark

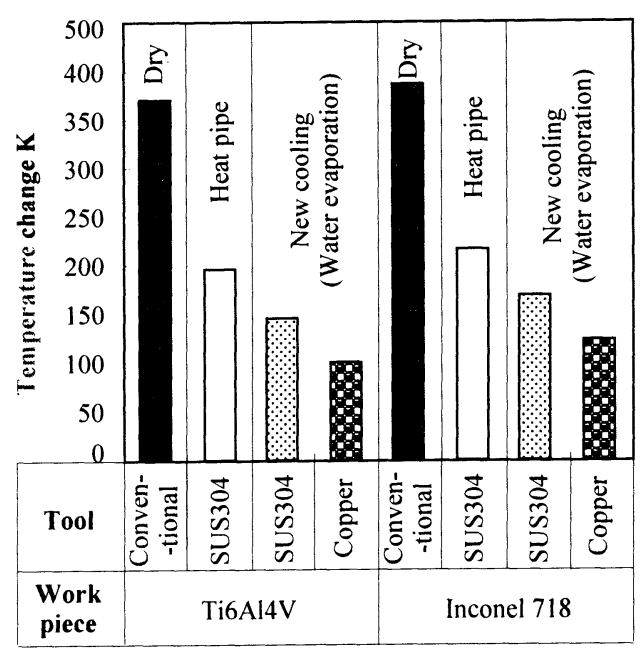

Fig. 10 Result of the temperature on the electrodeposited diamond tools
ずつ切り込まれ，紙面垂直方向に $50 \mathrm{~mm}$ 送られる. 加 工量測定方法は，図 9(b) に示すように，工作物側面に 予め $50 \mu \mathrm{m} \times 50 \mu \mathrm{m}$ の正方形模様を縦横 $90 \mu \mathrm{m}$ ピッチ で $\mathrm{YVO}_{4}$ マーキング用レーザで照射し，それを目印とし ながら研削断面積を測定した。図では電着工具先端部 分の形状が残っている. 工具寿命と判定した段階で, この研削断面積 $\times 50 \mathrm{~mm}$ (=1 パスの切削距離 $)$ を総加工 量とした。

3. 2 温度澌定の結果図 10 に温度測定結果を 示す，本報で開発した新しい電着工具と強制冷却シス テムのほかに, 工具本体材料 SUS304 と強制冷却システ 厶の場合, 従来から市販されている中実の電着工具の

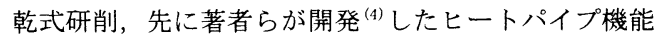
付き電着工具（工具本体が SUS304）の 4 種類の電着工 具を使用した。工作物は Ti6Al4V, Inconel 718 の 2 種 類である. 加工条件は表 2 のとおりである. 切込みは $3.0 \mu \mathrm{m}$ としたときの定常状態の温度上昇結果である. なお, この加工条件における気化熱泠却のための最適 な水供給量は，予備実験の結果からすべての工作物に ついて $180 \mathrm{ml} / \mathrm{h}$ （切込みは $3.0 \mu \mathrm{m}$ ）とした. 本報で 開発した新しい電着工具と強制冷却システムは, 従来 の電着工具の 4 倍, ヒートパイプ機能付き電着工具に 比べて 2 倍の冷却効果があった。 また, 工具本体材料 が銅の場合は，それが SUS304の場合に比べて 1.5 倍の 冷却効果があった。工具本体を銅に代えたことにより 見かけ上の熱伝導率を上げてヒートシンク特性を改善 したことと，ダイレクトに気化熱冷却をしたことがで き，冷却効率を上げたことにより，効果的な強制冷却 が可能になった.

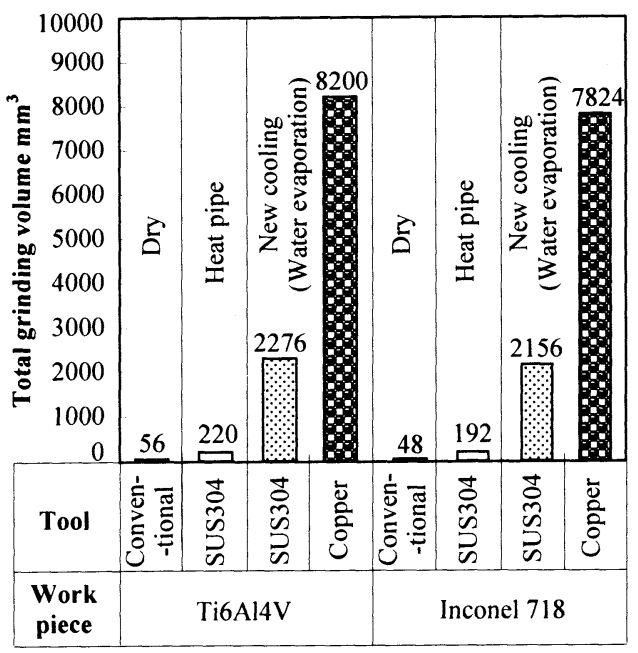

Fig. 11 Result of tool life test using several electrodeposited diamond tools 


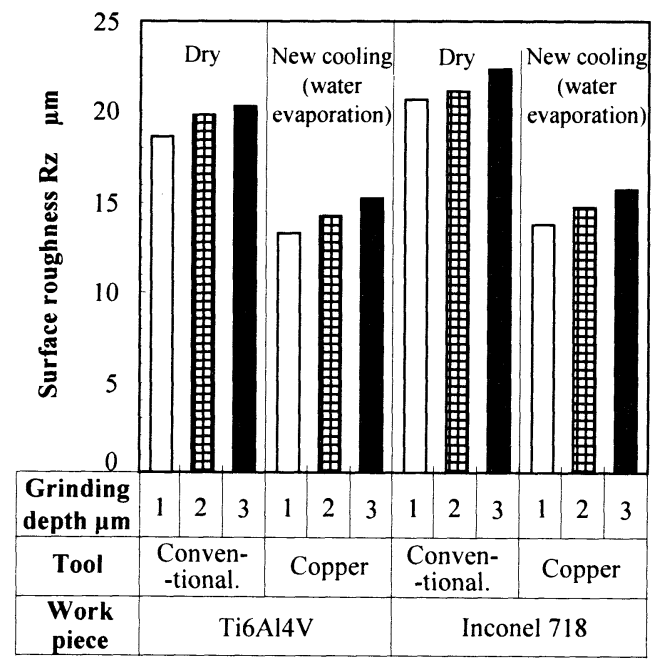

Fig. 12 Result of surface roughness using several electrodeposited diamond tools

\section{3 工具毒命の結果図 11 に工具寿命試験結} 果を示す. 工具は前節と同じ 4 種類の電着工具を使用 した. 工作物は Ti6Al4V と Inconel 718 の 2 種類であ る. 加工条件は表 2 のとおりで, 切り込みは $3 \mu \mathrm{m}$ であ る. 供給水量はすべての工作物について $180 \mathrm{ml} / \mathrm{h}$ とし た。本報で開発した新しい電着工具と強制冷却システ ムは, 従来の電着工具と比べて, Ti6A14V 合金を研削の 場合 146 倍に, Incone1 718 の場合 163 倍にそれぞれ 工具寿命が伸びた. ヒートパイプ機能付き電着工具に 比べて工具寿命が約 40 倍に伸びた. また工具本体材料 を銅に代えたことにより,それが SUS304 の場合と比べ て工具寿命が約 4 倍に伸びた. 開発した新しい電着工 具と強制冷却システムは，チタン合金やニッケル合金 などの熱伝導率が低く，工具の熱負担が大きくなるた めに難削性が指摘されている材料に対して, 十分な泠 却能力があり, 正常な工具寿命を維持できたと考える.

\section{4 表面粗さ 図 12 に切込み量を増加させた} 時の工作物の表面粗さの測定結果を示す。本報で開発 した新しい電着工具と強制冷却システムと, 従来から 市販されている中実の電着工具の 2 種類の電着工具を 使用した。工作物は Ti6Al4V, Incone1 718 の 2 種類で ある. 加工条件は表 2 のとおりである. 切込み量は 1.0 $\mu \mathrm{m}$ (供給水量 $120 \mathrm{ml} / \mathrm{h}$ ), $2.0 \mu \mathrm{m}$ (供給水量 $150 \mathrm{ml} / \mathrm{h}$ ), $3.0 \mu \mathrm{m}$ （供給水量 $180 \mathrm{ml} / \mathrm{h}$ ）である. 本報で開発した
新しい電着工具と強制冷却システムで研削する時の工 作物の表面粗さは従来の電着工具で研削する時の工作 物の表面粗さよりよく改善できた。本報で開発した新 しい電着工具と強制冷却システムは, 従来の電着工具 に比べて研削温度が低く，ダイヤモンド砥粒の硬度な ど機械的特性や切れ味が維持された状態で研削抵抗を 低く抑えられたことが原因と考える。

\section{4. 結 言}

本研究の結果をまとめると以下のとおりである.

（1）提案した電着工具は強制冷却能力が優れてい た.

（2）提案した方法で電着工具の工具寿命が延命化 でき，チタン合金やニッケル合金の高速研削が 可能であった。

（3）新しい電着工具と強制冷却システムは環境に 優しく，経済的な研削のツールであった.

\section{参考文献}

(1) NARUTAKI N.and YAMANE Y, High-speed machining of Inconel 718 with ceramic tools, Annals CIRP, 42(1), 1993, 103-106

(2) USUKI H.,SATO K., FERUYA S., High Speed Dry End Milling of Titanium Alloy with Coated Carbide Tool, Journal of the Japan Society for Precision Engineer, Vol. 71, No.4, 2005, 491-495

(3) KITAGAWA T., KUBO A. and MAEKAWA K., Temperature and wear of cutting tools in high-speed machining of Inconel 718 and Ti-6Al-6V-2Sn, Wear 202, Elsevier Science, 1997, 142-148

(4) Tanabe I., Binh H. T., SUGAI H. and INOUE M., Cutting with Heating of Work Piece and Cooling of Tool Regarding Cemented Carbide Mould and Die, Transactions of the Japan Society of Mechanical Engineer, Series C, Vol. 73, No. 727, 2007, 885-890.

(5) Tanabe,I. and Minh T. H., Cutting with an Environment-Friendly Cooling Method Using Water Evaporation (Establishment of This Cooling Method and Calculation of the Suitable Supply Quantity of Water), Transactions of the Japan Society of Mechanical Engineer, Series C, Vol. 67, No. 664, 2001, 4011-4016.

(6) Tanabe, I. et al, Turning with Environment-Friendly Cooling Method Using Water Evaporation $\left(2^{\text {nd }}\right.$ Report, Influence of Cutting Condition, Work Piece Material and Tip Material), Transactions of the Japan Society of Mechanical Engineer, Series C, Vol. 67, No. 656, 2001, 1182-1188.

(7) Tanabe, I. et al , Turning with Environment-Friendly Cooling Method Using Water Evaporation( $1^{\text {st }}$ Report, Cooling Effect of Water Evaporation and Its Applicability to Tool Tip Coolling), Transactions of the Japan Society of Mechanical Engineer, Series C, Vol. 66, No. 643, 2000, 1026-1030. 